\title{
Global geographical variation elemental and arsenic species concentration in paddy rice grain identifies a close association of essential elements copper, selenium and molybdenum with cadmium.
}

Prof. Andrew Meharg ( $\sim$ aa.meharg@qub.ac.uk)

Queen's University Belfast https://orcid.org/0000-0003-2019-0449

\section{Caroline Meharg}

Queen's University Belfast FMHS: Queen's University Belfast Faculty of Medicine Health and Life Sciences Manus Carey

Queen's University Belfast FMHS: Queen's University Belfast Faculty of Medicine Health and Life Sciences

Paul Williams

Queen's University Belfast FMHS: Queen's University Belfast Faculty of Medicine Health and Life Sciences

Zhengyu Shi

Queen's University Belfast

Katrina Campbell

Queen's University Belfast

Christopher Elliott

Queen's University Belfast

\section{Ernest Marwa}

Sokoine University of Agriculture

Xiao Jiujin

Sichuan Agricultural University

Júlia Gomes Farias

Universidade Federal de Santa Maria

Fernando Teixeira Nicoloso

Universidade Federal de Santa Maria

P. Mangala C.S. De Silva

University of Ruhuna

Ying Lu

South China Agricultural University

\section{Andy J. Green}

Estación Biológica de Doñana: Estacion Biologica de Donana CSIC

\section{Eduardo Moreno-Jiménez}

Universidad Autónoma de Madrid: Universidad Autonoma de Madrid

Angel Antonio Carbonell-Barrachina 
Universidad Miguel Hernández: Universidad Miguel Hernandez de Elche

\section{Alessia Sommella}

Università degli Studi di Napoli Federico II: Universita degli Studi di Napoli Federico II

\section{Massimo Pigna}

University of Naples Federico II: Universita degli Studi di Napoli Federico II

\section{Catherine Brabet}

CIRAD

\section{Didier Montet}

CIRAD

\section{Mahmud Hossain}

Bangladesh Agricultural University

\section{Rafiqul Islam}

Bangladesh Agricultural University

\section{Research Article}

\section{Keywords:}

Posted Date: March 1st, 2022

DOI: https://doi.org/10.21203/rs.3.rs-1372766/v1

License: (c) (i) This work is licensed under a Creative Commons Attribution 4.0 International License. Read Full License 


\section{Abstract}

Despite the centrality of staple grains for human well-being, both as a source of nutrients and of toxic ions, there is little understanding of where and how elements vary, and if there are particular elements that correlate. Here, for shop bought polished (white) rice we comprehensively characterize trace (arsenic species, cadmium, copper, iron, manganese, molybdenum, rubidium and zinc) and macro-nutrients (calcium, chlorine, potassium, phosphorus and sulphur) for grain purchased in 18 countries, across 4 continents, a total of 1045 samples, to investigate if there were any major differences between geographic location and elemental content, and to observe if there were any patterns in elemental distribution. Greatest variation in the median was observed for the non-essential rubidium (15-fold) and arsenic species (5-fold). Rubidium was highest in the Americas, lowest in Europe, while inorganic arsenic and dimethylarsonic acid (DMA) were low for Africa and high in the South American and European continents. Cadmium had the highest concentration in Asian samples and lowest in South America. Calcium, potassium, molybdenum and phosphorus, were highest in European and lowest in African grain, though the fold-differences were relatively low, $\sim 0.2$, while iron was highest in African grain and low in European, Asian and South American grain, with a 2-fold difference. Selenium was also higher in Africa versus other regions, and copper, manganese and zinc where highest in American grain. Factor analysis showed that copper, cadmium, molybdenum, rubidium and selenium were strongly associated together, and these element's factor loadings were diametrically opposed to less tightly associated calcium, chlorine, manganese, potassium, phosphorus and sulphur. Stepwise additions linear region analysis was performed on log transformed concentrations to investigate cadmium associations in more detail. Selenium was the greatest predictor of cadmium concentration, followed by molybdenum, accounting for over $50 \%$ of the contribution to the adjusted $\mathrm{R}^{2}$. Arsenic species were only weakly correlated with other elements. The implications for these findings with respect to dietary nutrition are discussed.

\section{Introduction}

Hidden hunger is one of the greatest issues facing society globally, defined as where food delivers adequate calories but is deficient in essential nutrients (Gashu et al., 2021). This is nowhere so prominent than in subsistence diets that rely on polished grains, where milling grains unfortunately removes a substantial portion of nutrients present in wholegrain (Rahman et al., 2019). Grain mineral nutrition varies due to soil conditions and cultivation and fertilization practice (Nyachoti et al., 2021; Gashu et al., 2021; Welsh and Graham, 2004; White and Broadlley, 2005) and to crop genetics (Cobb et al., 2021; Huang et al., 2015; Norton et al., 2014). Maximizing grain nutrient density to deliver as great a quantity of each essential element as feasible, given that bioavailability in the gut is also an issue for elements such as iron (Hoekenga et al., 2011), is a major goal for those wishing to improve human health (Gashu et al., 2021; Rahman et al., 2019).

Food security, supplying a population sufficient quantities of nutritionally balanced foods, has to be combined with food safety, minimizing exposure to toxic compounds. White rice is particularly problematic in both regards as it is not overly nutrient dense, while at the same time being widely elevated, $\sim 10$-fold compared to other grains, in cadmium and arsenic (Rahman et al., 2019). There is evidence that for certain elements such as arsenic (Williams et al., 2007), cadmium (Nan et al., 2002) and selenium (Zhu et al., 2009) that rice grain concentration is linked to the concentration in the soils in which they are grown. These 
elements tend to act as analogues of essential nutrients, phosphate and silicic acid for arsenic, dependant on whether arsenic is speciated as arsenate or arsenite, respectively (Meharg and Meharg, 2015.), nutrient divalent metal cations for cadmium (Schaaf et al., 2004), and sulphur for selenium (Zhu et al., 2009). The same is the case for non-essential rubidium, an analogue of essential potassium (Oliferuk et al., 2017). Most nutrient elements are thought to be in homeostasis with plant tissues, given that plant cells have quite stringent requirements for optimum functioning, and all elements/ions can be considered as stressors if outside those optimum activities in cells (Clemens, 2001; Ernst et al., 2008; Meharg, 1993). Some nutrients can be stored in excess through cellular sub-localization, or the formation of compounds/complexes suitable for storage. Phosphorus, an essential but generally poorly available in soils, undergoes both these storage strategies under luxury uptake, though plants rapidly downregulate phosphate assimilation if leaf tissue becomes too high (Chiou et al., 2006). Quantitative trait loci analysis, also indicates for some elements, notably cadmium, lead, selenium zinc, that grain accumulation is under genetic control in rice (Cobb et al., 2021; Huang et al., 2015; Norton et al., 2014). Given these complexities, for food security and safety mitigation strategies it is important to know how elemental concentrations vary regionally for foods, with rice, as a widely consumed dietary staple which can be low in nutrients but high in toxicants, being an obvious crop to investigate. Where problems are realised, deficiency or toxicity, mitigation for a specific region may include soil fertilization, water management, food supplementation or high grain nutrient directed breed strategies, i.e. food fortification of biofortification (Welsh and Graham, 2004; White and Broadley, 2005).

Global and regional assessments of grain mineral nutrition tend to focus on food fraud, using elemental analysis to try and identify geographical origin (Ariyama et al., 2012; Chung et al., 2018); or geo-nutrition, relating crop grain element concentrations to soils or regions of origin (Adomako et al., 2011; Gashu et al., 2021), with a number of studies also focusing on dietary consequences of grain elemental content (Gashu et al., 2021; Joy et al., 2017; Nyachoti et al., 2021). These studies tend to use inductively coupled plasma mass spectrometry (ICP-MS), and this has led to a better characterization of micro-elemental quantification, to which ICP-MS is suited, as compared to macro-elements that are generally too elevated in grains for adequate ICP-MS quantification, with the exception of phosphorus. XRF is better suited to macro-element analysis and is becoming more established in characterizing foods, given that issues with external calibration of XRF need to be overcome by using an appropriate range of Certified Reference Materials (CRMs) (Oliveira et al., 2020; Rahman et al., 2019). Also, for arsenic in particular, there is a need to speciate as toxicity and regulation are driven by inorganic arsenic content, yet rice grain can have highly variable concentrations of dimethylarsonic acid (DMA) (Adamoko et al., 2011; Carey et al., 2020). Here we report macro- and microelemental, along with arsenic species, concentrations of market white rice, chosen to reflect direct dietary consumption of 1045 samples, collected across 18 countries from four major rice growing continents; Africa, South America, Asia and Europe. Rice was analysed by ICP-MS, ion chromatography (IC)-ICP-MS (to ascertain arsenic species concentrations) and XRF. Data were interpreted to examine commonalities in elemental and species patterns, and to identify specific deficiency/toxicity issues for given regions/countries.

\section{Materials And Methods}

The sampling strategies are outlined in the publications Carey et al. (2020) and Shi et al. (2020). In brief, polished (white) rice was obtained from 18 countries, and 4 continents, from retail outlets so as to best 
characterize consumer exposure. In total 1045 samples are reported here, a subset from the 1180 reported in Carey et al. (2020) on arsenic speciation, and 2270 from Shi et al. (2020) on cadmium. The current dataset only reports samples where additional XRF characterization has been conducted, leading to reduced sample coverage, in both number and in countries assessed.

Rice samples were freeze dried milled and subsampled for ICP-MS, both for arsenic speciation and elemental totals, and for XRF, with ICP-MS protocols described in detail in Carey et al. (2020) and Shi et al. (2020), and XRF protocols in Rahman et al. (2019). Only elements with certified quantification for rice flour CRM NIST $1568 \mathrm{~b}$, which was run for all batches for all analysis, were reported. Also, reported elements also had to be within the range of $70-130 \%$ recovery to go forward for statistical analysis and reporting, with CRM recoveries and limits of detection (LOD) given in Table 1. As a range of elements can be quantified by both ICP-MS and XRF, and for these elements the technique with the best recovery of NIST rice flour CRM NIST $1568 \mathrm{~b}$ was selected for reporting, with the technique used for reported analysis listed in Table 1. Statistical analysis considered the data both as grouped by continent or as grouped by country. Kruskal-Wallis used to compare medians and stepwise linear regression to look at relationships between elements were conducted in SPSS v.27, and Principal Component Analysis (PCA) and Spearman's Rank correlation were conducted using GraphPad Prism v.9. 
Table 1

Certified refence materials (CRM) recoveries by ICP-MS and XRF for rice flour NIST 1568b.

\begin{tabular}{|lllllll|}
\hline $\begin{array}{l}\text { element/ } \\
\text { species }\end{array}$ & $\begin{array}{l}\text { certified value } \\
(\mathbf{m g} / \mathbf{k g})\end{array}$ & $\begin{array}{l}\text { recorded value } \\
(\mathbf{m g} / \mathbf{k g})\end{array}$ & S.E.M. & $\begin{array}{l}\text { recovery } \\
(\%)\end{array}$ & $\begin{array}{l}\text { instrum- } \\
\text { entaion }\end{array}$ & N \\
\hline DMA & 0.180 & 0.181 & 0.005 & 100 & IC-ICP-MS & 78 \\
\hline MMA & 0.012 & 0.010 & 0.000 & 87 & IC-ICP-MS & 78 \\
\hline inorg. As & 0.092 & 0.091 & 0.001 & 99 & IC-ICP-MS & 78 \\
\hline sum As sp. & 0.284 & 0.282 & 0.005 & 99 & IC-ICP-MS & 78 \\
\hline As & 0.285 & 0.228 & 0.004 & 80 & ICP-MS & 56 \\
\hline Ca & 118 & 116 & 2 & 98 & XRF & 143 \\
\hline Cd & 0.022 & 0.023 & 0.001 & 104 & ICP-MS & 56 \\
\hline Cl & 301 & 232 & 3 & 77 & XRF & 143 \\
\hline Cu & 2.35 & 1.84 & 0.05 & 78 & ICP-MS & 56 \\
\hline Fe & 7.42 & 5.79 & 0.18 & 78 & ICP-MS & 56 \\
\hline $\mathrm{K}$ & 1282 & 1061 & 12 & 83 & XRF & 143 \\
\hline Mn & 19.2 & 21.0 & 0.3 & 109 & XRF & 143 \\
\hline Mo & 1.45 & 1.42 & 0.01 & 98 & ICP-MS & 56 \\
\hline $\mathrm{P}$ & 1530 & 1325 & 11 & 87 & XRF & 143 \\
\hline $\mathrm{Rb}$ & 6.20 & 5.82 & 0.03 & 94 & XRF & 143 \\
\hline $\mathrm{S}$ & 1200 & 984 & 8 & 82 & XRF & 143 \\
\hline $\mathrm{Se}$ & 0.365 & 0.245 & 0.006 & 67 & ICP-MS & 56 \\
\hline $\mathrm{Zn}$ & 19.4 & 17.4 & 0.2 & 89 & XRF & 143 \\
\hline
\end{tabular}

\section{Results}

Medians, 25th and 75th percentiles are presented for elements and species by continent in Fig. 1. KruskalWallis analysis was used to investigate differences in medians between the 4 regions. For all elements and species presented here, all were significantly different between continents, all at $P<0.001$, with the exception of $\mathrm{Mn}(\mathrm{P}=0.002)$ and $\mathrm{Zn}(\mathrm{P}=0.032)$. Greatest variation in the median was observed for the non-essential rubidium, being highest in the Americas, lowest in Europe, with a 15-fold difference. Arsenic species, inorganic arsenic and DMA, were the next variable in their medians with both species being low in Africa and high in the South American and European continents, with a 5-fold difference, while inorganic arsenic was relatively high in Asia, but DMA low. Cadmium had a different profile, being highest in Asia and lowest in South America. A range of macro-nutrient elements, calcium, potassium, molybdenum and phosphorus, were highest in European and lowest in African grain, though the fold-differences were relatively low, 0.2. 
Conversely, iron was high in African grain and lowest in European, Asian and South American grain, 2-fold difference. Chloride was also high in African and Asian grain, as compared to American and. European. Selenium was also higher in Africa versus other regions. Copper, manganese and zinc where highest in American grain, though there was relatively good homeostasis in concentrations across the continents. Sulphur was also found to have a similar homeostasis.

Presentation of medians for individual countries are given in Table 2, and country medians as a percentage of overall country median in Fig. 2. Kruskal-Wallis analysis found that all counties differed in their median, all at $P<0.0001$ with the exception of zinc where $P=0.046$. Tanzania is particularly low in inorganic arsenic DMA, cadmium and rubidium, but high in chloride. Mali is low in selenium, along with Argentina, Paraguay, Uruguay South Korea, Indonesia and Spain. There is a 4-fold difference in selenium concentrations for countries across the globe. For some countries there are notable high or low concentrations for particular elements. South Korea is high in calcium compared to all other countries, while Vietnam is particularly low in this element. Cadmium is specifically highly elevated in China, while other Asian countries also tend to be high in this element, $\sim 500 \%$ higher than the global mean. Chloride is elevated in Chile, phosphorus in Sri Lanka, and sulphur in Bangladesh. Bangladesh is specifically low in zinc, with a median $70 \%$ of that of the overall country medians, but high in iron at $200 \%$ of the median (Fig. 2). Countries with notably low macroand micro-nutrient elements are South Korea for copper, Chile and Sri Lanka for sulphur, zinc in Uruguay and Argentina, and particularly low zinc for Bangladesh, with almost half the concentration of this element compared to other countries. Vietnam is notable as it is deficient in calcium, iron, potassium, manganese and molybdenum, and no other country matches this broad pattern of macro- and micro- nutrient deficiencies (Fig. 2). For Africa, a depletion in arsenic species is apparent, as is elevation in selenium (Tanzania and Ivory Coast) and iron (universally) (Fig. 2). There is a specific elevation in Ivory Coast grain cadmium relative to other African countries (Fig. 2). What distinguishes American countries, with the exception of Bolivia, from other regions of the world are that they vary from moderate to highly elevated DMA, $300 \%$, and are relatively depleted in selenium especially in Argentina, Paraguay and Uruguay. Asian countries tend to be elevated in cadmium, but interestingly not South Korea. European rice was high in DMA and low in rubidium, and Italy was relatively high in cadmium. Turkish rice was notably low, $~ 50 \%$, in selenium. 
Table 2

Medians and 25 and 75 th percentiles for each element by country with units reported in $\mathrm{mg} / \mathrm{kg}$.

\begin{tabular}{|c|c|c|c|c|c|c|c|c|c|}
\hline & Asi & & & DMA & & & $\mathrm{Ca}$ & & \\
\hline & median & 25th & 75th & median & 25th & 75th & median & 25th & 75th \\
\hline Tanzania & 0.009 & 0.0275 & 0.0055 & 0.003 & 0.008 & 0.002 & 39.8 & 47.3 & 36 \\
\hline Ivory Coast & 0.0492 & 0.0747 & 0.0142 & 0.013 & 0.019 & 0.004 & 42.8 & 51.1 & 35.1 \\
\hline Mali & 0.0696 & 0.089 & 0.0193 & 0.032 & 0.04 & 0.013 & 46.3 & 57.7 & 40.9 \\
\hline Argentina & 0.0614 & 0.0867 & 0.0488 & 0.045 & 0.149 & 0.03 & 40.1 & 47.6 & 37.8 \\
\hline Bolivia & 0.0724 & 0.0984 & 0.0521 & 0.032 & 0.047 & 0.009 & 52.2 & 60.7 & 36.3 \\
\hline Brazil & 0.0688 & 0.0899 & 0.0484 & 0.071 & 0.105 & 0.019 & 41.4 & 58.4 & 34 \\
\hline Chile & 0.0634 & 0.0716 & 0.0599 & 0.113 & 0.141 & 0.081 & 53.4 & 76.7 & 45.4 \\
\hline Paraguay & 0.1074 & 0.1393 & 0.0954 & 0.086 & 0.12 & 0.05 & 39.6 & 55.6 & 34.8 \\
\hline Uruguay & 0.0679 & 0.087 & 0.0614 & 0.105 & 0.13 & 0.066 & 43.1 & 63.2 & 39.2 \\
\hline China & 0.0823 & 0.0946 & 0.072 & 0.025 & 0.033 & 0.019 & 51.1 & 61.3 & 41.2 \\
\hline $\begin{array}{l}\text { South } \\
\text { Korea }\end{array}$ & 0.0639 & 0.0812 & 0.0552 & 0.016 & 0.019 & 0.011 & 79.9 & 99.5 & 65.9 \\
\hline Bangladesh & 0.1116 & 0.1502 & 0.0794 & 0.028 & 0.037 & 0.013 & 55.2 & 67.3 & 37.9 \\
\hline Sri Lanka & 0.0355 & 0.0543 & 0.0234 & 0.002 & 0.006 & 0.001 & 43.8 & 66.8 & 34.9 \\
\hline Indonesia & 0.0325 & 0.0501 & 0.0152 & 0.004 & 0.007 & 0.001 & 43.9 & 58.8 & 36 \\
\hline Vietnam & 0.0679 & 0.0852 & 0.0556 & 0.025 & 0.033 & 0.018 & 29.3 & 36.8 & 25.8 \\
\hline Italy & 0.0943 & 0.1151 & 0.0706 & 0.059 & 0.092 & 0.036 & 52.2 & 58.9 & 47.8 \\
\hline Spain & 0.0621 & 0.084 & 0.0469 & 0.054 & 0.092 & 0.023 & 40.3 & 54.8 & 33.7 \\
\hline \multirow[t]{2}{*}{ Turkey } & 0.0757 & 0.0904 & 0.0682 & 0.033 & 0.065 & 0.027 & 50.8 & 58.4 & 42.4 \\
\hline & $\mathrm{Cl}$ & & & Cd & & & $\mathrm{Cu}$ & & \\
\hline Tanzania & median & 25th & 75th & median & 25th & 75th & median & 25th & 75th \\
\hline Ivory Coast & 234 & 274 & 187 & 0.0049 & 0.0049 & 0.0049 & 1.74 & 2.07 & 1.47 \\
\hline Mali & 183 & 201 & 159 & 0.0217 & 0.0347 & 0.0176 & 1.83 & 2.18 & 1.51 \\
\hline Argentina & 135 & 156 & 123 & 0.0172 & 0.0238 & 0.0049 & 1.98 & 2.28 & 1.7 \\
\hline Bolivia & 126 & 139 & 113 & 0.0049 & 0.012 & 0.0049 & 1.95 & 2.11 & 1.83 \\
\hline Brazil & 115 & 182 & 100 & 0.023 & 0.0697 & 0.0049 & 2.45 & 2.85 & 2.19 \\
\hline Chile & 142 & 164 & 125 & 0.0122 & 0.0175 & 0.0049 & 2.21 & 3.02 & 1.7 \\
\hline
\end{tabular}




\begin{tabular}{|c|c|c|c|c|c|c|c|c|c|}
\hline & Asi & & & DMA & & & $\mathrm{Ca}$ & & \\
\hline Paraguay & 275 & 304 & 253 & 0.0049 & 0.0049 & 0.0049 & 1.94 & 2.23 & 1.9 \\
\hline Uruguay & 168 & 187 & 142 & 0.0049 & 0.0049 & 0.0049 & 2.41 & 2.54 & 2.32 \\
\hline China & 154 & 178 & 122 & 0.0049 & 0.0082 & 0.0049 & 1.7 & 1.73 & 1.39 \\
\hline $\begin{array}{l}\text { South } \\
\text { Korea }\end{array}$ & 218 & 237 & 190 & 0.0539 & 0.118 & 0.0103 & 1.98 & 2.31 & 1.78 \\
\hline Bangladesh & 170 & 194 & 145 & 0.0154 & 0.0242 & 0.0116 & 1.38 & 1.7 & 1.2 \\
\hline Sri Lanka & 175 & 202 & 151 & 0.0247 & 0.0432 & 0.017 & 1.56 & 1.93 & 1.41 \\
\hline Indonesia & 173 & 219 & 135 & 0.0285 & 0.0588 & 0.0168 & 2.24 & 2.85 & 1.65 \\
\hline Vietnam & 223 & 259 & 194 & 0.0208 & 0.0337 & 0.0114 & 1.59 & 1.81 & 1.25 \\
\hline Italy & 186 & 214 & 155 & 0.019 & 0.0345 & 0.0134 & 1.72 & 2.27 & 1.34 \\
\hline Spain & 142 & 157 & 130 & 0.0261 & 0.0401 & 0.014 & 2.07 & 2.65 & 1.72 \\
\hline \multirow[t]{3}{*}{ Turkey } & 176 & 191 & 154 & 0.0049 & 0.0086 & 0.0049 & 1.72 & 2.01 & 1.31 \\
\hline & 186 & 206 & 162 & 0.0049 & 0.0126 & 0.0049 & 2.03 & 2.44 & 1.65 \\
\hline & $\mathrm{Fe}$ & & & $\mathrm{K}$ & & & $\mathrm{Mn}$ & & \\
\hline Tanzania & median & 25th & 75th & median & 25th & 75th & median & 25th & 75th \\
\hline Ivory Coast & 6.52 & 8.58 & 5.27 & 812 & 910 & 744 & 12.5 & 14.15 & 10.75 \\
\hline Mali & 7.79 & 15.37 & 5.72 & 777 & 863 & 690 & 9.16 & 10.75 & 7.8 \\
\hline Argentina & 7.64 & 11.44 & 6.52 & 926 & 1443 & 597 & 11.75 & 14.25 & 7.86 \\
\hline Bolivia & 4.02 & 4.49 & 3.62 & 832 & 928 & 787 & 10.46 & 11.15 & 9.49 \\
\hline Brazil & 3.75 & 5.49 & 3.19 & 581 & 800 & 511 & 10.85 & 16.83 & 9.79 \\
\hline Chile & 4.28 & 5.78 & 3.78 & 797 & 1258 & 579 & 12.25 & 15.4 & 10.53 \\
\hline Paraguay & 4.43 & 5.55 & 3.02 & 1010 & 1860 & 908 & 12.6 & 23.35 & 9.99 \\
\hline Uruguay & 4.54 & 6.21 & 4.13 & 592 & 677 & 531 & 10.6 & 11.8 & 9.71 \\
\hline China & 4.32 & 4.54 & 4.08 & 793 & 1190 & 665 & 12 & 13.15 & 9 \\
\hline $\begin{array}{l}\text { South } \\
\text { Korea }\end{array}$ & 4.5 & 5.22 & 3.84 & 670 & 859 & 599 & 12.65 & 14.53 & 10.63 \\
\hline Bangladesh & 5.53 & 7.32 & 4.74 & 1050 & 1370 & 908 & 16 & 21.78 & 13.38 \\
\hline Sri Lanka & 7.9 & 11.72 & 6.18 & 1160 & 1488 & 1098 & 8.62 & 12.25 & 1.68 \\
\hline Indonesia & 5.69 & 7.44 & 4.6 & 1125 & 1378 & 978 & 10.8 & 14.98 & 9.32 \\
\hline Vietnam & 4.5 & 6.66 & 4.09 & 748 & 838 & 632 & 10.85 & 13.6 & 9.37 \\
\hline
\end{tabular}




\begin{tabular}{|c|c|c|c|c|c|c|c|c|c|}
\hline & Asi & & & DMA & & & $\mathrm{Ca}$ & & \\
\hline Italy & 3.74 & 4.12 & 3.41 & 560 & 690 & 493 & 9.17 & 10 & 8.14 \\
\hline Spain & 4.63 & 5.05 & 4.21 & 991 & 1160 & 870 & 11.8 & 13.93 & 10.08 \\
\hline \multirow[t]{3}{*}{ Turkey } & 4.43 & 4.71 & 3.98 & 816 & 947 & 748 & 9.58 & 11.93 & 7.75 \\
\hline & 3.68 & 4.05 & 3.11 & 811 & 921 & 737 & 10.07 & 11.93 & 8.63 \\
\hline & Mo & & & $\mathbf{P}$ & & & & $\mathrm{Rb}$ & \\
\hline Tanzania & median & 25th & 75th & median & 25th & 75th & median & 25th & 75th \\
\hline Ivory Coast & 0.536 & 0.621 & 0.379 & 842 & 932 & 791 & 2.07 & 5.53 & 1.101 \\
\hline Mali & 0.463 & 0.669 & 0.385 & 799 & 929 & 704 & 4.148 & 5.875 & 2.278 \\
\hline Argentina & 0.61 & 0.784 & 0.398 & 850 & 1171 & 624 & 7.034 & 11.152 & 3.531 \\
\hline Bolivia & 0.549 & 0.558 & 0.43 & 1014 & 1106 & 902 & 2.365 & 6.182 & 1.096 \\
\hline Brazil & 0.737 & 0.917 & 0.597 & 681 & 734 & 614 & 1.085 & 1.707 & 0.743 \\
\hline Chile & 0.595 & 0.714 & 0.493 & 1112 & 1702 & 850 & 7.011 & 12.133 & 4.753 \\
\hline Paraguay & 0.552 & 0.569 & 0.509 & 805 & 1784 & 744 & 9.52 & 21.794 & 7.886 \\
\hline Uruguay & 0.699 & 0.739 & 0.607 & 785 & 837 & 723 & 6.61 & 8.098 & 4.308 \\
\hline China & 0.459 & 0.565 & 0.402 & 703 & 815 & 679 & 7.677 & 9.767 & 4.853 \\
\hline $\begin{array}{l}\text { South } \\
\text { Korea }\end{array}$ & 0.529 & 0.634 & 0.446 & 685 & 762 & 637 & 3.256 & 4.405 & 2.604 \\
\hline Bangladesh & 0.452 & 0.505 & 0.405 & 898 & 1204 & 800 & 2.881 & 3.991 & 1.966 \\
\hline Sri Lanka & 0.595 & 0.814 & 0.51 & 969 & 1109 & 848 & 8.982 & 11.948 & 6.598 \\
\hline Indonesia & 0.579 & 0.75 & 0.441 & 1408 & 1880 & 1106 & 6.178 & 10.633 & 3.221 \\
\hline Vietnam & 0.484 & 0.573 & 0.411 & 794 & 963 & 682 & 3.293 & 5.157 & 2.279 \\
\hline Italy & 0.425 & 0.553 & 0.336 & 707 & 999 & 578 & 3.751 & 5.784 & 1.98 \\
\hline Spain & 0.782 & 0.988 & 0.625 & 1321 & 1474 & 1186 & 0.761 & 1.127 & 0.487 \\
\hline \multirow[t]{4}{*}{ Turkey } & 0.351 & 0.4 & 0.315 & 1022 & 1098 & 915 & 0.723 & 1.527 & 0.461 \\
\hline & 0.519 & 0.623 & 0.458 & 842 & 916 & 772 & 0.818 & 1.222 & 0.597 \\
\hline & $S$ & & & Se & & & $\mathrm{Zn}$ & & \\
\hline & median & 25th & 75th & median & 25th & 75th & median & 25th & 75th \\
\hline Tanzania & 861 & 980 & 794 & 0.0354 & 0.0602 & 0.0235 & 9.88 & 11.10 & 9.01 \\
\hline Ivory Coast & 837 & 892 & 774 & 0.0441 & 0.0653 & 0.0216 & 10.26 & 11.48 & 8.81 \\
\hline
\end{tabular}




\begin{tabular}{|c|c|c|c|c|c|c|c|c|c|}
\hline & Asi & & & DMA & & & $\mathrm{Ca}$ & & \\
\hline Mali & 731 & 810 & 696 & 0.016 & 0.0277 & 0.0103 & 10.78 & 11.51 & 6.88 \\
\hline Argentina & 799 & 834 & 794 & 0.0103 & 0.016 & 0.0103 & 8.22 & 9.06 & 7.53 \\
\hline Bolivia & 793 & 945 & 737 & 0.0214 & 0.0353 & 0.0103 & 11.28 & 13.46 & 10.28 \\
\hline Brazil & 786 & 842 & 725 & 0.0238 & 0.0359 & 0.0103 & 11.98 & 14.66 & 9.36 \\
\hline Chile & 680 & 742 & 644 & 0.0333 & 0.0356 & 0.0276 & 11.37 & 13.89 & 10.96 \\
\hline Paraguay & 784 & 816 & 752 & 0.0103 & 0.0103 & 0.0103 & 11.80 & 12.47 & 10.70 \\
\hline Uruguay & 778 & 855 & 751 & 0.0103 & 0.0179 & 0.0103 & 7.91 & 9.11 & 6.62 \\
\hline China & 880 & 942 & 829 & 0.0226 & 0.0354 & 0.0103 & 11.66 & 12.35 & 11.37 \\
\hline $\begin{array}{l}\text { South } \\
\text { Korea }\end{array}$ & 809 & 877 & 740 & 0.0103 & 0.0103 & 0.0103 & 9.52 & 11.22 & 8.81 \\
\hline Bangladesh & 1015 & 1093 & 944 & 0.0275 & 0.0357 & 0.0217 & 5.92 & 8.18 & 4.41 \\
\hline Sri Lanka & 712 & 788 & 664 & 0.0412 & 0.0651 & 0.0267 & 11.03 & 13.26 & 8.18 \\
\hline Indonesia & 911 & 1020 & 856 & 0.0103 & 0.0227 & 0.0103 & 10.45 & 11.41 & 9.23 \\
\hline Vietnam & 890 & 952 & 842 & 0.0234 & 0.037 & 0.0103 & 12.39 & 14.59 & 11.03 \\
\hline Italy & 839 & 888 & 777 & 0.0366 & 0.0429 & 0.0305 & 10.05 & 11.83 & 8.52 \\
\hline Spain & 862 & 905 & 810 & 0.0103 & 0.0103 & 0.0103 & 9.15 & 10.27 & 7.79 \\
\hline Turkey & 780 & 837 & 726 & 0.0271 & 0.0354 & 0.0103 & 10.19 & 11.10 & 8.88 \\
\hline
\end{tabular}

PCA and associated Factor Analysis for the entire data set are presented in Fig. 3. The PCA score means by country are given with the individual scores due to the high data density. The factor loadings analysis showed that copper, cadmium, molybdenum, rubidium and selenium were strongly associated together, and these element's factor loadings were diametrically opposed to less tightly associated calcium, chlorine, manganese, potassium phosphorus and sulphur, with similar strengths of loadings. Inorganic arsenic and zinc were also associated, but less strongly, with this latter cluster. Iron and DMA had factor loadings close to the origin, suggesting that there were not closely associated with any other elements. Element/species pairs that might be thought to be associated with other are diametrically opposed such as: copper and zinc (elevated concentrations of both derived from the same pollutant sources); inorganic arsenic and cadmium (again being derived in elevated concentrations in soil through pollutant sources); the physiological analogues sulphur and selenium. However, potassium and phosphorus Factor Loadings were similar in direction and strength, which may relate to the fact that these two elements are commonly fertilized together. The American countries, with the exception of Chile, were associated with the copper, cadmium, molybdenum, rubidium and selenium Factor Loadings, but the countries of other continents were dispersed around the plot, though the nearby countries of Mali and Ivory Coast differed considerably in cadmium content. Vietnam, in particular has a mean PCA score to the right of the graph but near to the X-axis. This shows, again, that 
Vietnamese grains are generally nutrient deficient, as shown by plots of the country value of each element expressed as a percentage of the median of country medians given in Table 2 and percentages of medians in Fig. 3.

To validate/cross reference the PCA factor loading observations for cadmium, log transformed elemental concentrations underwent stepwise additions linear regression with log cadmium concentration as the dependent variable (Table 3). Selenium was the greatest predictor of cadmium, followed by molybdenum, accounting for over $50 \%$ of the contribution to the adjusted $\mathrm{R}^{2}$. Log inorganic arsenic in stepwise linear regression was highly correlated with log DMA with an adjusted $R^{2}$ of 0.556 , but not with other elements. When log DMA was removed as a predictor, the next highest correlating parameter was log molybdenum with an adjusted $R^{2}$ of 0.029 (data not tabulated).

Table 3. Stepwise regression analysis of log cadmium grain concentrations verses the log transformed other elements quantified. Section A shows the $\mathrm{R}^{2}$ and the significance of each model, while $\mathrm{B}$ shows the slopes (Beta) and significance for the model containing all elements in the final model.

A.

\begin{tabular}{lllllr} 
Model & R & $\begin{array}{l}\text { R } \\
\text { Square }\end{array}$ & $\begin{array}{l}\text { Adjusted R } \\
\text { Square }\end{array}$ & $\begin{array}{l}\text { Std. Error of the } \\
\text { Estimate }\end{array}$ & Sign. \\
\hline Se & $.274^{\mathrm{a}}$ & 0.075 & 0.074 & 0.41024 & $<0.0001$ \\
\hline $\mathrm{Se}, \mathrm{Mo}$ & $.325^{\mathrm{b}}$ & 0.106 & 0.104 & 0.40364 & $<0.0001$ \\
\hline $\mathrm{Se}, \mathrm{Mo}, \mathrm{DMA}$ & $.388^{\mathrm{c}}$ & 0.151 & 0.148 & 0.39350 & $<0.0001$ \\
\hline $\mathrm{Se}, \mathrm{Mo}, \mathrm{DMA}, \mathrm{iAs}$ & $.454^{\mathrm{d}}$ & 0.206 & 0.203 & 0.38062 & $<0.0001$ \\
\hline $\mathrm{Se}, \mathrm{Mo}, \mathrm{DMA}, \mathrm{iAs}, \mathrm{Cl}$ & $.477^{\mathrm{e}}$ & 0.228 & 0.224 & 0.37559 & $<0.0001$ \\
\hline $\mathrm{Se}, \mathrm{Mo}, \mathrm{DMA}, \mathrm{iAs}, \mathrm{Cl}, \mathrm{S}$ & $.493^{\mathrm{f}}$ & 0.243 & 0.239 & 0.37193 & $<0.0001$ \\
\hline $\mathrm{Se}, \mathrm{Mo}, \mathrm{DMA}, \mathrm{iAs}, \mathrm{Cl}, \mathrm{S}, \mathrm{Cu}$ & $.506^{\mathrm{g}}$ & 0.256 & 0.251 & 0.36895 & $<0.0001$ \\
\hline $\mathrm{Se}, \mathrm{Mo}, \mathrm{DMA}, \mathrm{iAs}, \mathrm{Cl}, \mathrm{S}, \mathrm{Cu}, \mathrm{P}$ & $.516^{\mathrm{h}}$ & 0.266 & 0.260 & 0.36675 & $<0.0001$ \\
\hline $\mathrm{Se}, \mathrm{Mo}, \mathrm{DMA}, \mathrm{iAs}, \mathrm{Cl}, \mathrm{S}, \mathrm{Cu}, \mathrm{P}$, & $.521^{\mathrm{i}}$ & 0.272 & 0.265 & 0.36546 & $<0.0001$ \\
\hline $\mathrm{Zn}$ & & & & $<0.0001$ \\
\hline $\mathrm{Se}, \mathrm{Mo}, \mathrm{DMA}, \mathrm{iAs}, \mathrm{Cl}, \mathrm{S}, \mathrm{Cu}, \mathrm{P}$, & $.526^{\mathrm{j}}$ & 0.277 & 0.270 & 0.36437 & \\
\hline $\mathrm{Zn}, \mathrm{Rb}$ & & & & &
\end{tabular}

B. 


\begin{tabular}{llll} 
& Beta & T & Sign. \\
\hline Constant & & -3.694 & $<0.001$ \\
\hline Se & 0.163 & 5.507 & $<0.001$ \\
\hline Mo & 0.141 & 4.536 & $<0.001$ \\
\hline DMA & -0.564 & -13.289 & $<0.001$ \\
\hline As $($ V $)$ & 0.453 & 10.724 & $<0.001$ \\
\hline Cl & -0.203 & -6.876 & $<0.001$ \\
\hline S & 0.122 & 4.138 & $<0.001$ \\
\hline Cu & 0.117 & 3.895 & $<0.001$ \\
\hline $\mathbf{P}$ & -0.124 & -4.289 & $<0.001$ \\
\hline Zn & 0.097 & 3.269 & 0.001 \\
\hline Rb & 0.074 & 2.680 & 0.007
\end{tabular}

Figure 4 shows the correlation matrix for the log transformed concentration dataset to enable further comparisons of all elements/species against each other. Besides the strong positive correlation between inorganic arsenic and DMA, there was also a very strong relationship between potassium and phosphorus (Spearman's R of 0.799). This strong association between potassium and phosphorus is also seen for the Factor Analysis (Fig. 3). Also notable from the Spearman's rank correlation is that chlorine is negatively correlated with a suite of elements/species including arsenic species, cadmium, copper, molybdenum, phosphorus and rubidium.

\section{Discussion}

Plant nutrition is dependent on soil availability and concentration, and plant physiological regulation as determined by genetics (Cobb et al., 2021; Norton et al., 2014). It is considered that most essential elements and ions are in homeostasis for plant tissues in general, and in grain specifically, as outside individual ion/element concentration range the plant will either be in deficiency or toxicity (Bohnert et al., 2006). One essential element that does not appear under tight physiological control, with grain concentration being closely related to soil concentrations is selenium (Zhu et al., 2009). This is thought to be because selenium species are analogues of the much more abundant sulphur, and with sulphur ameliorating selenium species toxicity (Zhu et al., 2009). Non-essential elements/ions also enter grain as analogues of essential nutrients, such as: arsenate, a phosphate analogue (Meharg, 1993); arsenite, a silicic acid analogue (Meharg and Meharg, 2015); rubidium, a potassium analogue (Oliferuk et al., 2017); and cadmium an analogue of a range 
of divalent cations (Nan et al., 2002). Thus, a key finding here is that essential elements copper, molybdenum and selenium are tightly associated with non-essential cadmium and rubidium. Hypotheses regarding the relationship between cadmium with copper, molybdenum, rubidium and selenium are now considered.

Copper and selenium can be elevated in soils due to anthropogenic processes, such as mineral smelting and processing and coal burning, where selenium soil pollution actually supplements plants as it is deficient in most soils (Zhu et al., 2015). As noted, selenium can be very variable in plant tissues while copper is under tight plant homeostasis due its essentiality in a range of cellular functions and due to its toxicity (Clemens et al., 2001). Contrastingly to copper, a divalent metal ion that is also an environmental contaminant, divalent cadmium is also a widely dispersed pollutant that can reach concentrations in grain that cause human health concerns in a wide range of agricultural settings, yet is highly variable in grain (Hu et al., 2016; Nan et al., 2002; Shi et al., 2020). Rubidium differs yet again, being a monovalent ion, and is thought to be preferentially mobilized into plants under acidic soil conditions where soil available potassium is low (Drobner and Tyler, 1998). Molybdenum chemistry in soils and plants is complex, with molybdate thought to be a sulphate analogue, and is assimilated by plants more readily at higher $\mathrm{pHs}$ due to reduced binding adsorption to amorphous oxides, while sulphur addition also decreased molybdenum assimilation (McGrath et al., 2010). In the context of the close assimilation of the group of elements found to cluster here (cadmium with copper, molybdenum, rubidium and selenium), cadmium is most studied (Hu et al., 2015; Hu et al., 2016; Shi et al., 2020). Cadmium is assimilated under more aerobic conditions of rice cultivation (Hu et al., 2015) and this may be a clue as to why other elements are associated with cadmium, i.e. it could be hypothesised that more aerobic conditions are needed to mobilize these elements in paddy soils effectively. This supposition remains to be tested.

Cadmium, in both soils and plants, is readily complexed by sulphur (Ernst et al., 2008). High grain cadmium is diametrically opposed to high grain sulphur for Factor Loading plots, and thus when sulphur is high in plants it can be postulated that translocation of cadmium to grain is low as cadmium complexation with sulphur groups of phytochelatins (PCs) are sequestered in the vacuole, retarding their translocation to the plant (Ernst et al., 2008). It is sulphide immobilization under reduced redox conditions that causes cadmium to have poor soil availability under flooded paddy conditions (de Livera et al, 2011; Rinklebe et al., 2016), again emphasizing the intimate link between cadmium and sulphur highlighted in this current study. This sulphur association may also explain grain copper concentrations, with copper like cadmium having a high affinity for sulphur (Ernst et al., 2008; Hartley-Whitaker et al., 2001). Notably, selenium is a sulphur analogue (Zhu et al., 2009). For selenium, the ratio of selenium to sulphur increases, maybe as the plant tries to mine plant sulphur, inadvertently assimilating more selenium, i.e. that selenium may be increased in grain under sulphur deficiency. The same could be argued for rubidium and potassium, i.e. that rubidium is enhanced in grain when potassium is deficient, as rubidium is orthogonal to potassium with respect to its grain PCA Factor Loading plot. Molybdenum is assimilated through plant roots as molybdate (Baxter et al., 2008), an anion that is thought to interact strongly with sulphate (McGrath et al., 2010), i.e. that it is postulated that molybdate is a sulphate analogue. Molybdenum is assimilated into grain when sulphur is low, according to PCA analysis, suggesting that under plant sulphur deficiency conditions that molybdenum is more readily assimilated and translocated. Interestingly, Williams et al. (2009) found that grain zinc and selenium was negatively correlated with grain arsenic for field sites across Bangladesh. Thus elemental toxicity, arsenic in

Page $14 / 23$ 
this case, is impacting grain nutritional composition. For the current study, Bangladesh had the highest grain arsenic of this survey and the lowest zinc, supporting this finding, but the selenium grain concentration was median.

The global distribution of arsenic species in polished grain has been previously studied for this data-set (Carey et al., 2020). What is new here is the understanding that both inorganic arsenic and DMA are not intimately linked to other elements with respect to co-location in grain. Arsenic species mobilization is strongly driven by soil redox, linked to the dissolution of iron plaque and to the microbial methylation of inorganic arsenic (Meharg and Zhao, 2012). It is notable that grain iron is also not strongly linked to other elements in this current investigation. It appears that other factors, such as potential pollution impact and weathering of soils, have a greater influence on grain arsenic species than co-element nutrition of plant or soils, given that arsenic species can also act as phosphate and silicic acid analogues in both soils and plants (Meharg and Zhao, 2012). For example, it is the low pollutant impacted and heavy weathered soils of African and Asian southern hemispheres that are low in grain arsenic species in this current study.

With respect to genetic variation in grain elemental content, Norton et al. (2010) investigating 17 elements in grain through ICP-MS quantification found for an indica-japonica cross that there were 41 QTLs. QTLs for iron, molybdenum, selenium and zinc, in particular, were suggested to be suitably strong to be targets for improving grain concentrations through marker assisted selection. Huang et al. (2015) reported genetic variation in cadmium, iron, lead, selenium, and zinc, for wholegrain rice using Chinese association mapping accessions. Genome-wide association mapping found a strong genotype*environment interaction for loci associated with elements in whole grain rice grown at 4 locations across the globe, but variation was found for arsenic, copper, molybdenum and zinc (Norton et al., 2014), indicating weak genetic links between the elements. Genetic variation was found to be a large determining factor for grain arsenic concentrations across four field sites globally, Bangladesh, China, India and N. America (Norton et al. 2011). Association mapping has identified root and shoot transporters for cadmium and molybdenum, but these are on different loci and are for different putative transporters (Cobb et al., 2021). Thus rice genetics, particularly between japonica and indica groups (Huang et al., 2015, Norton et al., 2010), could be an important source of variation in rice's global grain supply chain, but this needs to be systematically investigated in order to validate.

The data sets reported here enable rice from different regions to be grouped as deficient in particular nutrients. The key country with respect to globally mineral nutrient deficiency in the grain was Vietnam as its grain was particularly deficient in a suite of macro- and micro- nutrients, while also being relatively elevated in cadmium. These deficiencies in grain elemental nutrients suggest that Vietnamese soils may be generally deficient in nutrients. This may be due to a range of factors such as over cropping as many Vietnamese paddies have multiple harvests per year (Ba et al., 2016). Soil acidification is widespread in S.E. Asia due to over use of mineral nitrogen fertilizers (Xie et al., 2019), and acidification will lead to issues with nutrient leaching and availability. Straw biomass is widely burnt in Vietnam leading to poor organic waste-stream recycling, including animal manures produced through straw consumption (Hung and Hughes, 2019; Watanabe et al., 2019). The health consequences for the Vietnamese population for having rice low in nutrient density but high in toxicants needs assessing, given that it is a subsistence rice economy with high rates of per capital consumption (Hung et al., 2019; Watanabe et al., 2017). Another notable health concern is 
Bangladesh that has high inorganic arsenic, high cadmium and low zinc, given that zinc is vital in enzymatic roles that are key to the general health of the population (Williams et al., 2009). The low selenium content of rice is of concern for a range of South American countries, and for Spain, South Korea and Indonesia, because selenium deficiency is implicated in a wide range of disease outcomes at a population level (Zhu et al., 2009).

The research findings of this current study provide the basis to start to redress dietary deficiencies in populations that have rice as a subsistence diet. This could be through changing agronomic practices or ensuring key nutrients reach the diet through other food groups. The underlying rice grain nutrient deficiencies reported here require further epidemiological studies to investigate human consequences, and agronomic investigations with respect to how to mitigate against deficiencies through soil management and rice breeding

\section{Declarations}

\section{Conflict of interest: none}

Data availability: will be issued on reasonable request

\section{Acknowledgement: none}

Author contributions: AAM and CM were involved with supervision and writing. MC, ZS, XJ and JGF conducted the analysis. All other authors helped in sourcing samples. All authors were involved in proofing and correcting the submitted manuscript.

\section{References}

1. Adomako EE, Williams PN, Deacon C, Meharg AA (2011) Inorganic arsenic and trace elements in Ghanaian grain staples. Environ Poll 159:2435-2442

2. Ariyama K, Shinozaki M, Kawasaki A (2012) Determination of the Geographic Origin of Rice by Chemometrics with Strontium and Lead Isotope Ratios and Multielement Concentrations. J Agri Food Chem 60:1628-1634

3. Ba LT, Van KL, Van Elsacker S, Cornelis WM (2016) Effects of cropping system on physical properties of clay soil under intensive rice cultivation. Land Degr Devol 27:973-982

4. Baxter I, Muthukumar B, Park HC, Buchner P, Lahner B, Danku J, Zhao K, Lee J, Hawkesford MJ, Guerinot $\mathrm{ML}$, Salt DE (2008) Variation in molybdenum content across broadly distributed populations of Arabidopsis thalian is controlled by a mitochondrial molybdenum transporter (MOT1). PLOSgenetics 4, e1000004

5. Bohnert HJ, Gong QQ, Li PH, Ma SS (2006) Unraveling abiotic stress tolerance mechanisms - getting genomics going. Cu Opin Plant Biol 9:180-188

6. Carey M, Meharg C, Williams P, Marwa E, Jiujin X, Gomes Farias J, De Silva PMCS, Signes-Pastor A, Lu Y, Nicoloso FT, Savage L, Campbell K, Elliott C, Adomako E, Green AJ, Moreno-Jiménez E, Carbonell- 
Barrachina AA, Triwardhani EA, Pandiangan FI, Haris PI, Lawgali YF, Sommella A, Pigna M, Brabet C, Montet D Njira K, Watts MJ, Meharg AA (2020) Global sourcing of low-inorganic arsenic rice grain. Expos Health 12:711-719

7. Chiou TJ, Aung K, Lin SI, Wu CC, Chiang SF, Su CL (2006) Regulation of phosphate homeostasis by microRNA in Arabidopsis. Plant Cell 18:412-421

8. Chung I-M, Kim J-K, Lee K-J, Park J-H, Son N-Y, Jin Y-I, Kim S-H (2018) Geographic authentication of Asian rice (Oryza sativa L.) using multi-elemental and stable isotopic data combined with multivariate analysis. Food Chem 240:840-849

9. Clemens S (2001) Molecular mechanisms of plant metal tolerance and HomeostasisPlanta212,475-486

10. Cobb JN, Chen C, Shi Y, Maron LG, Liu, Rutzke M, Greenberg A, Craft E, Shaff J, Paul E, Akther K, Wang S, Kochian LV, Zhang D, Zhang M, McCouch SR (2021) Genetic architecture of root and shoot ionomes in rice (Oryza sativa L.). Theoret App Genet 134:2613-2637

11. de Livera J, McLaughlin MJ, Hettiarachchi GM, Kirby JK, Beak DG (2011) Cadmium solubility in paddy soils: effects of soil oxidation, metal sulfides and competitive ions. Sci Total Environ 409:1489-1497

12. Drobner U, Tyler G (1998) Conditions controlling relative uptake of potassium and rubidium by plants from soils. Plant Soil 201:285-293

13. Ernst WHO, Krauss GJ, Verkleij JAC, Wessenberg D (2008) Interaction of heavy metals with the sulphur metabolism in angiosperms from an ecological point of view. Plant Cell Environ 31:123-143

14. Gashu D, Nalivata PC, Amede T, Ander EL, Bailey EH, Botoman L, Chagumaria C, Gameda S, Haefele SM, Hailu K, Joy EJM, Mossa AW, Munthali M, Towett EK, Walsh MG, Wilson L, Young SD, Broadley MR (2021) The nutritional quality of cereals varies geospatially in Ethiopia and Malawi. Nature 594:71-76

15. Hartley-Whitaker J, Ainswort G, Meharg AA (2001) Copper and arsenate induced oxidative stress in Holcus lanatus L. clones with differential sensitivity. Plant Cell \& Environ 24:713-722

16. Hu P, Ouyang Y, Wu L, Shen L, Luo Y, Christie P (2015) Effects of water management on arsenic and cadmium speciation and accumulation in an upland rice cultivar. J Environ Sci 27:225-231

17. Hu Y, Cheng H, Tao S (2016) The challenges and solutions for cadmium-contaminated rice in China: a critical review. Environ Intern 92-93:515-532

18. Hoekenga OA, Lung'aho MG, Tako E, Kochian LV, Glahn RP (2011) Iron biofortification of maize grain. Plant Genet Res-Charact Utiliz 9:327-329

19. Huang Y, Sun C, Min J, Chen Y, Tong C, Bao J (2015) Association mapping of quantitative trait loci for mineral element contents in whole grain rice (Oryza sativa L.). Agric Food Chem 63:10885-10892

20. Hung DT, Hughes HJ, Keck M, Sauer D (2019) Rice-residue management practices of smallholder farms in Vietnam and their effects on nutrient fluxes in the soil-plant system. Sustain 11:1641

21. Joy EJM, Ander EL, Broadley MR, Young SS, Chilimba ADC, Hamilton EM, Watts MJ (2017) Elemental composition of Malawian rice. Environ Geochem Health 39:835-845

22. McGrath SP, Mico C, Curdy R, Zhao FJ (2010) Predicting molybdenum toxicity to higher plants: influence of soil properties. Environ Pollut 158:3095-3102

23. Meharg AA (1993) The role of the plasmalemma in metal tolerance in angiosperms. Physiol Plant 88:191-198 
24. Meharg C, Meharg AA (2015) Silicon, the silver-bullet for mitigating biotic and abiotic stress, and improving grain quality, in rice. Environ Exp Bot 120:8-17

25. Meharg AA, Zhao F-J (2012) Arsenic \& Rice. Springer-Verlag, Berlin Nan Z, Li J, Zhang J, Cheng G (2002) Cadmium and zinc interactions and their transformations in soil-crop system under actual field conditions. Sci Total Environ 285:187-195

26. Norton GJ, Deacon CM, Xiong L, Meharg AA, Price AH (2010) Genetic mapping of the rice ionome in leaves and grain: Identification of QTLs for 17 elements including arsenic, cadmium, iron and selenium. Plant Soil 329:139-153

27. Norton GJ, Douglas A, Lahner B, Yakubova E, Guerinot ML, Pinson SRM, Tarpley L, Eizenga E, McGrath SP, Zhao FJ, Islam MR, Islam S, Duan G, Zhu YG, Salt DE, Meharg AA, Price AH (2014) Genome wide association mapping of grain arsenic, copper, molybdenum and zinc in rice (Oryza sativa L.) grown at four international field sites. PLOSone 9, e89685

28. Norton GJ, Zhu YG, Meharg AA, Price AH (2012) Identification of quantitative trait loci for rice grain element composition on an arsenic impacted soil: Influence of flowering time on genetic loci. Annals Appl Biol 161:46-56

29. Nyachoti S, Godebo TR, Okwori O, Jeuland MA, Manthrithilake H (2021) Dietary exposures to metals in relation to chronic kidney disease of unknown cause (CKDu) in Sri Lanka. Exposure Health. https://doi.org/10.1007/s12403-021-00418-4

30. Oliferuk S, Rodenas R, Perez A, Martinez V, Rubio F, Santa-Maria GE (2017) DELLAs contribute to set the growth and mineral composition of Arabidopsis thaliana plants grown under conditions of potassium deprivation. J Plant Growth Reg 36:487-501

31. Oliveira LB, dos Santos WPC, Teixeira LSG, Korn MGA (2020) Direct analysis of cocoa powder, chocolate powder, and powdered chocolate drink for multi-element determination by energy dispersive X-ray fluorescence spectrometry. Food Anal Meth 13:195-202

32. Rahman H, Carey M, Hossain M, Savage L, Islam MR, Meharg AA (2019) Modifying the parboiling of rice to remove inorganic arsenic, while fortifying with calcium. Environ Sci Technol 53:5249-5255

33. Rinklebe J, Shaheen SM, Yu KW (2016) Release of As, Ba, Cd, Cu, Pb, and Sr under pre-definite redox conditions in different rice paddy soils originating from the USA and Asia. Geoderma 270:21-32

34. Schaaf G, Ludewig U, Erenoglu BE, Mori S, Kitahara T, von Wiren N (2004) ZmYS1 functions as a protoncoupled symporter for phytosiderophore- and nicotianamine- chelated metals. J Biol Chem 279:90919096

35. Shi Z, Carey M, Meharg C, Williams P, Signes-Pastor AJ, Triwardhani EA, Pandianga FI, Campbell K, Elliott C, Marwa E, Xia J, Gomes Farias J, Nicoloso FT, De Silva PMCS, Lu Y, Norton G, Adomako E, Green AJ, Moreno-Jimenez E, Carbonell-Barrachina ÁA, Haris PI, Lawgali YF, Sommella A, Pigna M, Brabet C, Montet D, Njira K, Watts MJ, Hossain M, Islam MR, Tapia Y, Orport C, Meharg AA (20) Rice grain cadmium concentrations in the global supply-chain. Exp Health 12, 869-876

36. Watanabe T, Luu HM, Inubushi K (2017) Effects of continuous applications of rice straw compost and chemical fertilizer on soil carbon and available silicon under double rice cropping systems in the Mekong Delta, Vietnam. Japan Agric Res Quart 51:233-239 
37. Welsh RM, Graham RD (2004) Breeding for micronutrients in staple food crops from a human nutrition perspective. J Ex Bot 55:353-364

38. White PJ, Broadley MR (2005) Biofortifying crops with essential mineral elements. Tr Plant Sci 10:586593

39. Williams PN, Islam S, Islam R, Jahiruddin M, Adomako E, Soliaman ARM, Rahman GKMM, Zhu YG, Meharg AA (2009) Arsenic compromise trace mineral nutrition (selenium, zinc, and nickel) in Bangladesh rice grain. Environ Sci Technol 43:8430-8436

40. Williams PN, Villada A, Deacon C, Raab A, Figuerola J, Green AJ, Feldmann J, Meharg AA (2007) Greatly enhanced arsenic shoot assimilation in rice leads to elevated grain levels compared to wheat and barley. Environ Sci Technol 41:6854-6859

41. Xie EZ, Zhao YC, Li HD, Shi XZ, Lu FY, Zhang Z, Peng YX (2019) Spatio-temporal changes of cropland soil $\mathrm{pH}$ in a rapidly industrializing region in the Yangtze River Delta of China 1980-2015. Agric Ecosys Environ 272:95-104

42. Zhu YG, Pilon-Smits EAH, Zhao FJ, Williams PN, Meharg AA (2009) Selenium in higher plants: understanding mechanisms for biofortification and phytoremediation. Trends Plant Sci 14:436-442

\section{Figures}



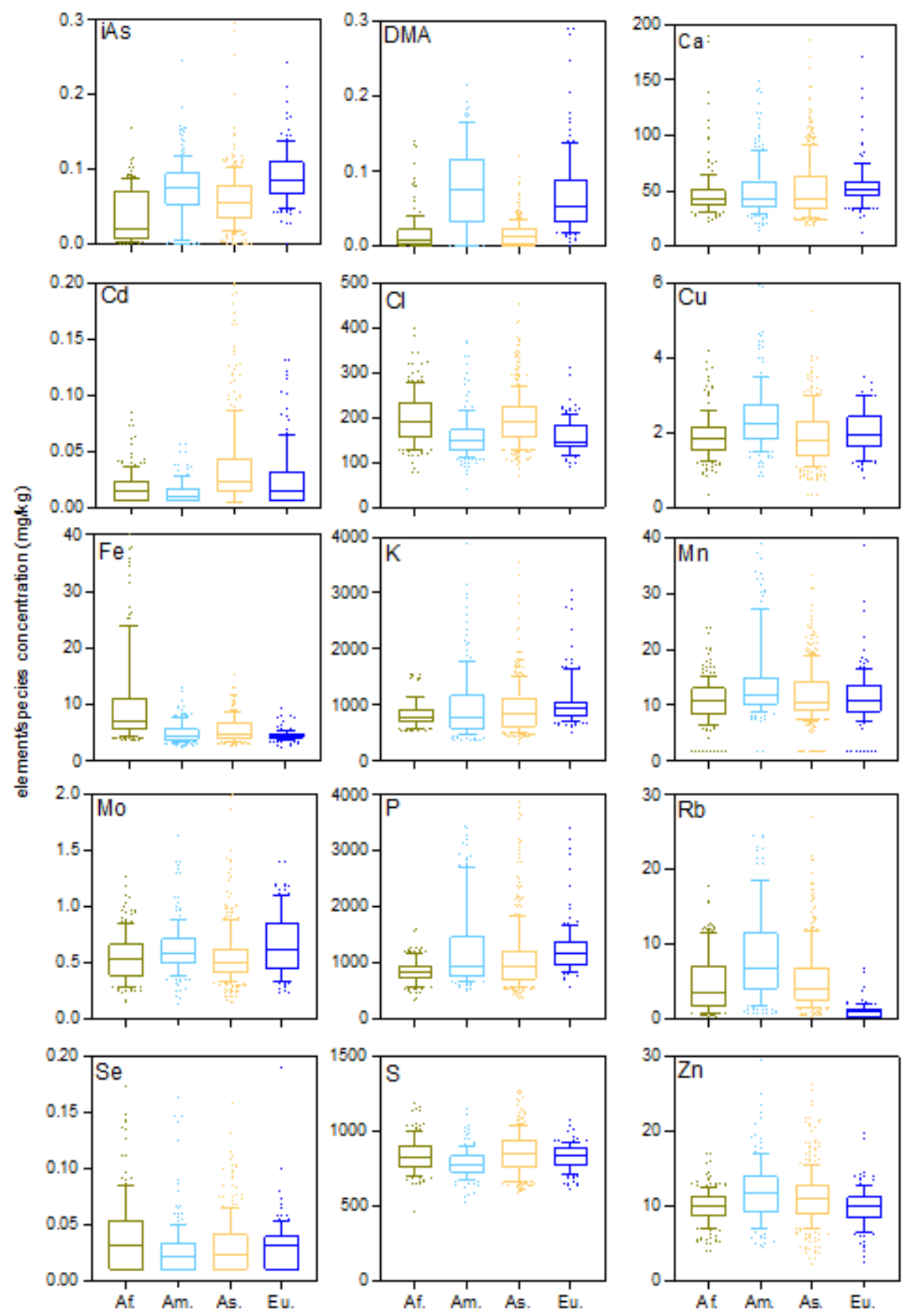

Figure 1

Boxplots of Median (central line), 25 and $75^{\text {th }}$ (outer box), 5 and $95^{\text {th }}$ (whiskers) and outliers for each element by continental region: green, Africa; light blue, South America; yellow, S.E. Asia; dark blue, Europe 

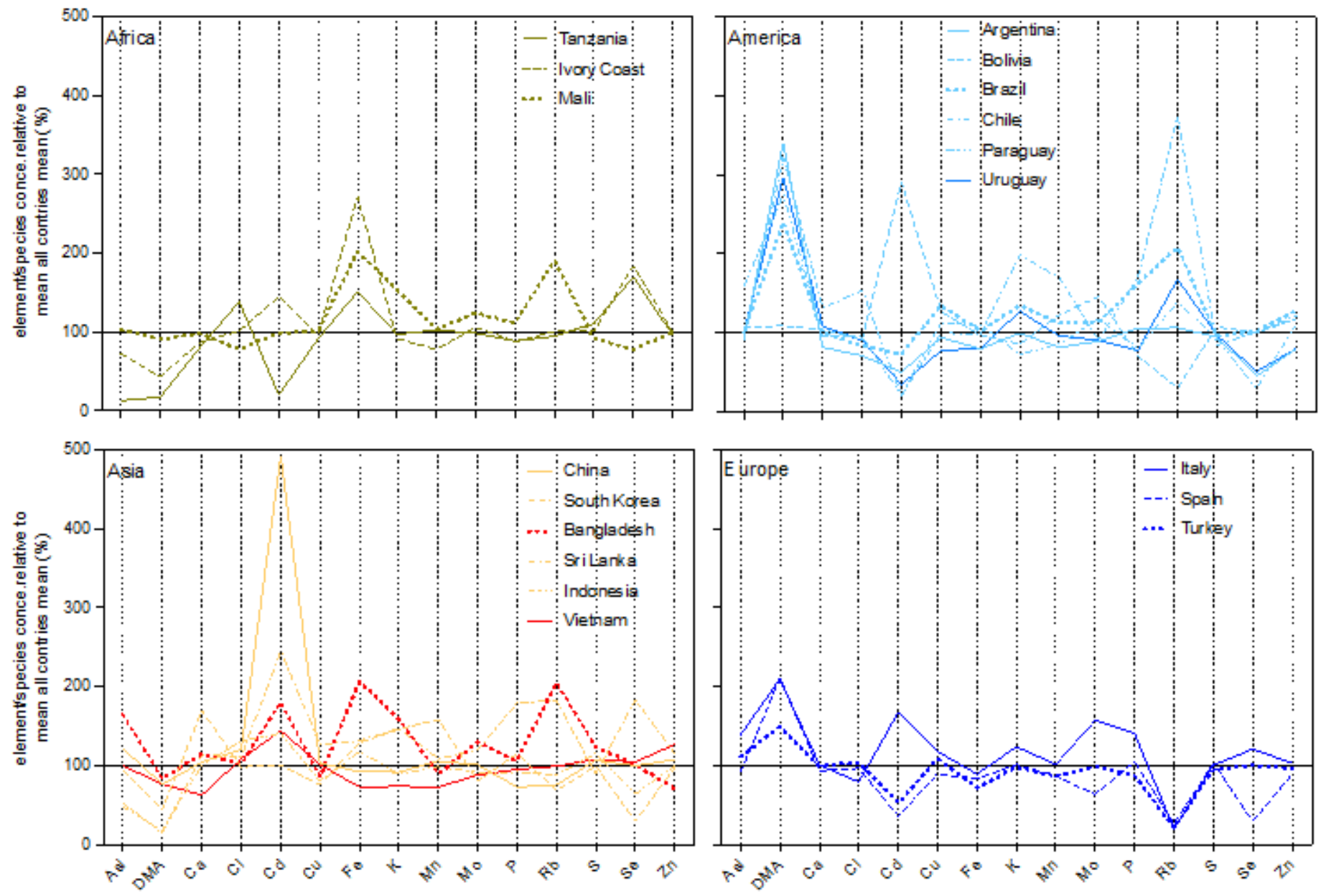

Figure 2

Country medians expressed as a percentage relative to the mean of all countries for each element, plotted by continent. 


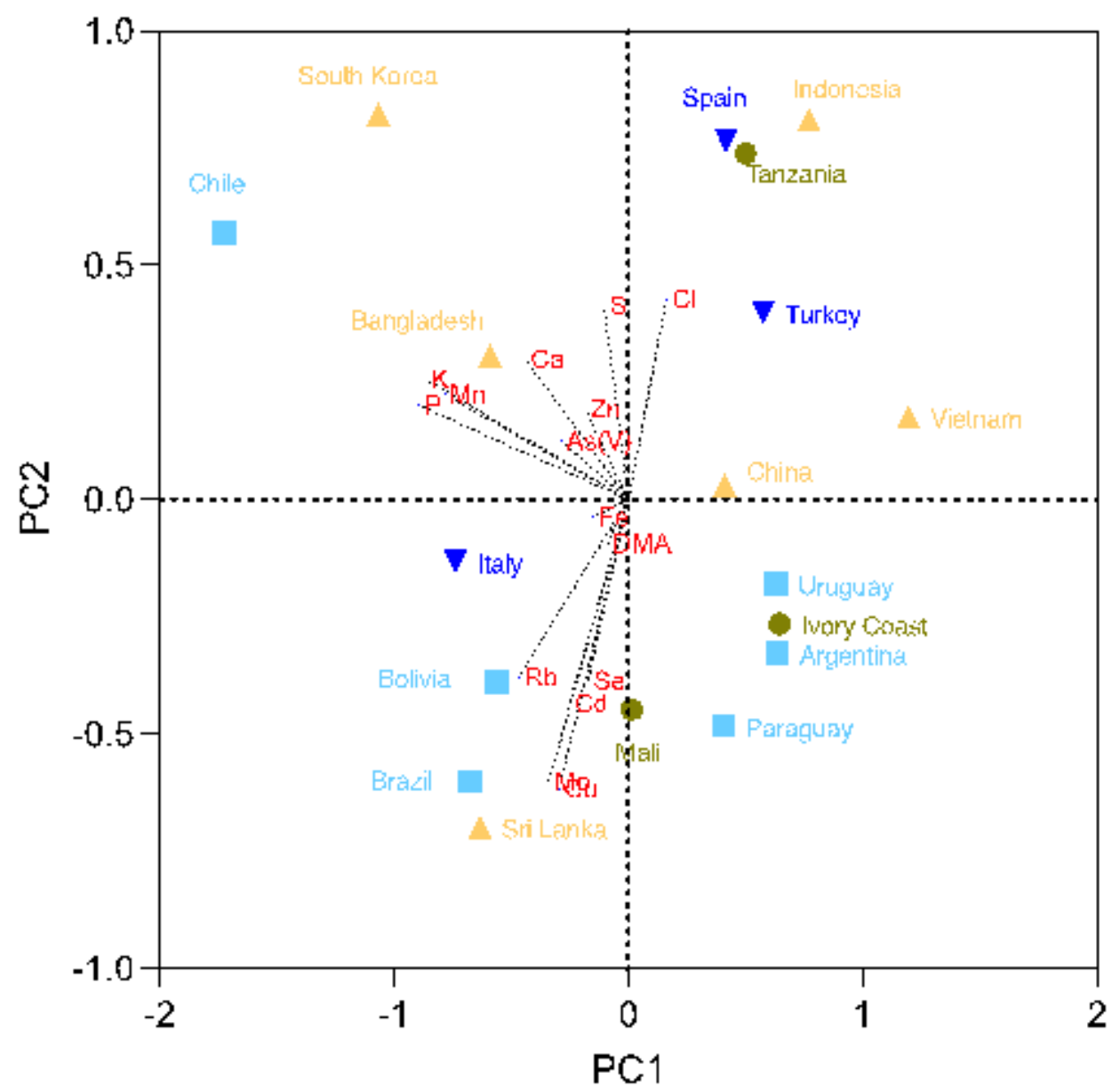

Figure 3

Factor loading plot for the principal component analysis (PCA) overlain with PCA scores means by country.

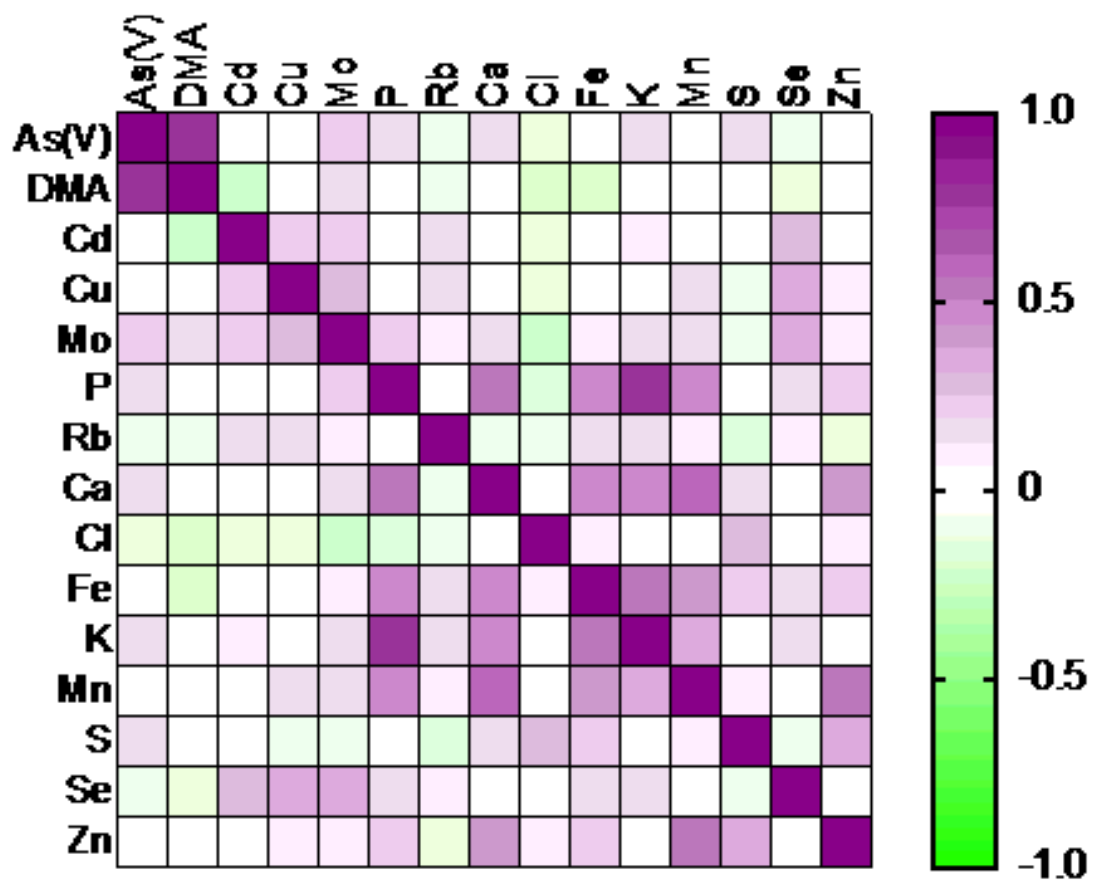


Figure 4

Correlation matrix of log transformed elements for rice grain concentrations. 